\title{
Blood group Lewis phenotype on erythrocytes and in saliva in alcoholic pancreatitis and chronic liver disease
}

\author{
LENNART STIGENDAL,${ }^{*}$ ROLF OLSSON,${ }^{*}$ LENNART RYDBERG,$\dagger$ \\ BO E SAMUELSSON†
}

From the *Department of Internal Medicine II and the †Regional Blood Centre, Sahlgren's Hospital, University of Gothenburg, Gothenburg, Sweden

SUMMARY The distributions of $\mathrm{ABO}$, rhesus, and Lewis blood group antigens were studied in patients with alcoholic cirrhosis, alcoholic pancreatitis, chronic active hepatitis, and primary biliary cirrhosis. There were no differences in frequencies of $\mathrm{ABO}$ and rhesus blood group antigens between the groups or in comparison with a control group of blood donors. Lewis phenotype Le $(a-b-)$, however, was more common on erythrocytes than in saliva in patients with alcoholic cirrhosis, alcoholic pancreatitis, and severe renal disease but equally common in saliva and on red blood cells in patients with non-alcoholic liver disease. It is suggested that Lewis typing should be performed on saliva because blood typing may give misleading results in some patients.

During studies of possible genetic predispositions to alcohol induced organ damage blood group $\mathrm{ABO}$, rhesus, and Lewis typing was performed on patients with alcoholic liver cirrhosis and alcoholic pancreatitis. Patients with chronic active hepatitis, primary biliary cirrhosis, and severe renal disease were also studied to observe the effect of liver damage or severe disease per se on the occurrence of Lewis antigens.

\section{Patients and methods}

\section{PATIENTS}

1 Fifty one men and 10 women with presumed alcoholic cirrhosis. The diagnosis of cirrhosis was based on findings at liver biopsy or necropsy in 31 men and five women. In the remaining cases the clinical and laboratory criteria for diagnosis were:

(a) hepatomegaly, spider naevi; palmar erythema, and ascites, of which at least two were fulfilled;

(b) serum bilirubin above $60 \mu \mathrm{mol} / \mathrm{l}$, coagulation factors II, VII, and X less than $40 \%$ of normal, and serum albumin less than $30 \mathrm{~g} / \mathrm{l}$, of which at least one was fulfilled. In all patients a history of excessive alcohol intake for many years was given, and the clinical course did not indicate malignant disease as the primary cause of the liver dysfunction.

2 Thirty three men with presumed alcoholic pancreatitis. The diagnosis of pancreatitis was based on a typical history, absence of evidence of other causes of the symptoms, and increased serum or urinary amylase values. The patients were admitted to hospital because of an acute attack following a period of heavy alcohol abuse.

3 Seven men and 15 women with chronic active hepatitis. The diagnosis was based on liver biopsy in all patients. All sera gave negative test results for hepatitis B surface antigen. Nine patients were positive for antinuclear or smooth muscle antibodies.

4 Four men and 21 women with primary biliary cirrhosis. The diagnosis was based on liver biopsy with a positive test for antimitochondrial antibodies in all patients.

5 Two hundred and ninety seven patients with severe chronic renal disease, requiring dialysis in most patients, were included for comparison of Lewis antigen frequency.

6 Ninety seven unrelated healthy relatives of the patients with renal disease (43 men, 54 women), representing normal subjects, were also included for comparison of Lewis antigen frequency. 


\section{METHODS}

$A B O$ and rhesus blood grouping. $\mathrm{ABO}$ and rhesus antigens were identified using standard blood grouping techniques.

Screening for irregular antibodies. Sera were tested for the presence of irregular antibodies (that it, Lewis antibodies) using standardised screening cells and at least two different well established techniques.'

Lewis blood grouping. Determination of the Lewis phenotype on erythrocytes was carried out using goat anti-Le antiserum and human anti-Le ${ }^{b}$ antiserum (Biotest Serum Institute. Frankfurt/M, West Germany). The typing procedure was performed at least twice on each blood sample and always with appropriate positive and negative controls. When divergent results were obtained in two tests the results obtained in two out of three tests were accepted. Determination of Lewis antigens in saliva was performed as follows. A few millilitres of saliva was collected from the patients. The saliva was boiled for $10 \mathrm{~min}$, centrifuged, and the supernatant analysed immediately or frozen at $-20^{\circ} \mathrm{C}$. Determination was performed by a haemagglutination inhibition technique using serial dilutions of saliva in saline.'

Tests for the presence of Lewis antigens in serum. Adsorption of possible $\mathrm{Le}^{\mathrm{a}}$ or $\mathrm{Le}^{\mathrm{b}}$ antigens from serum on red blood cells was performed as described elsewhere.' The erythrocytes used for adsorption were standard test cells of the $O$ Le $(a-b-)$ type. The presence of adsorbed Lewis antigens was tested with a conventional haemagglutination technique (see above). Sera from healthy blood donors of the A Le $(a-b+)$ and A Le $(a-b-)$ types were used as positive and negative controls, respectively.

Secretor status. Detection of $\mathrm{H}$ substance in saliva was performed by a haemagglutination inhibition technique' using extract of Ulex europaeus (Dade Division American Hospital Supply Corporation, Miami, Florida).

STATISTICAL ANALYSIS

Student's $t$ test was used for comparison of means and $\chi^{2}$ analysis for comparison of frequencies. The level of significance was $5 \%$.

\section{Results}

A significantly increased prevalence of the red cell phenotype Le $(a-b-)$ was found in the alcoholic cirrhosis, alcoholic pancreatitis, and renal disease groups as compared with normal controls (Table 1). In addition, the patients with alcoholic cirrhosis had a higher prevalence of Le $(a-b-)$ than the renal disease group, and the patients with primary biliary cirrhosis had higher prevalence of $\operatorname{Le}(a+b-)$ than the renal disease group.

The study originally included only patients with alcoholic cirrhosis or acute pancreatitis. When it became apparent that these patients often had no detectable Lewis antigens (phenotype Le $(a-b-)$ ) on their red blood cells, it became of interest to determine whether they also lacked Lewis antigens in saliva and to include patients with other chronic liver diseases (chronic active hepatitis and primary biliary cirrhosis). Unfortunately, by that time many of the patients with alcoholic cirrhosis and alcoholic pancreatitis originally studied were no longer alive or willing to cooperate. Thus Lewis antigens were determined in the saliva of only 33 men and 10 women with alcoholic cirrhosis, 17 patients with alcoholic pancreatitis, and in all patients with chronic active hepatitis or primary biliary cirrhosis.

There were no significant differences between the tested groups in the prevalence of secretors or of Lewis phenotypes in saliva (Table 2). A comparison of the results of blood and saliva testing performed in the same patient showed a significantly higher frequency of the Le $(a-b-)$ phenotype on red blood cells compared with saliva in patients with alcoholic cirrhosis or alcoholic pancreatitis (Table 3 ). Routine antibody screening showed no antiLewis antibodies in the sera of patients with the Le $(a-b-)$ phenotype.

Sera from some patients typed as Le $(a-b-)$ on red blood cells but Le $(a-b+)$ or Le $(a+b-)$ in saliva were tested for their ability to coat $\operatorname{Le}(a-b-)$

Table 1 Prevalence of Lewis antigens on red blood cells

\begin{tabular}{|c|c|c|c|c|}
\hline & No of patients & Le $(a-b-)$ & $L e(a+b-)$ & $L e(a-b+)$ \\
\hline $\begin{array}{l}\text { Alcoholic cirrhosis } \\
\text { Men } \\
\text { Women } \\
\text { Alcoholic pancreatitis } \\
\text { Chronic active hepatitis } \\
\text { Primary biliary cirrhosis } \\
\text { Renal disease } \\
\text { Normal controls }\end{array}$ & $\begin{array}{r}51 \\
10 \\
33 \\
22 \\
26 \\
297 \\
97\end{array}$ & $\begin{array}{r}28(55 \%)^{*} \\
5(50 \%)^{*} \\
12(36 \%)^{*} \\
4(18 \%) \\
4(15 \%) \\
68(23 \%) \\
13(13 \%)\end{array}$ & $\begin{array}{r}5(10 \%)^{*} \\
1 \quad(10 \%) \\
5(15 \%) \\
5(23 \%) \\
9(35 \%) \\
47(16 \%) \\
20(21 \%)\end{array}$ & $\begin{array}{r}18(35 \%)^{*} \\
4(40 \%) \\
16(49 \%) \\
13(59 \%) \\
13(50 \%) \\
182(61 \%) \\
64(66 \%)\end{array}$ \\
\hline
\end{tabular}

*Significant difference compared with normal controls. 
Table 2 Prevalence of Lewis antigens in saliva and secretor status

\begin{tabular}{|c|c|c|c|c|c|}
\hline & No of patients & Le $(a-b-)$ & Le $(a+b-)$ & $\operatorname{Le}(a-b+)$ & Secretor \\
\hline $\begin{array}{l}\text { Alcoholic cirrhosis } \\
\text { Men } \\
\text { Women } \\
\text { Alcoholic pancreatitis } \\
\text { Chronic active hepatitis } \\
\text { Primary biliary cirrhosis }\end{array}$ & $\begin{array}{l}33 \\
10 \\
17 \\
22 \\
26\end{array}$ & $\begin{array}{l}5(15 \%) \\
0 \\
2(12 \%) \\
1 \quad(4 \%) \\
5(19 \%)\end{array}$ & $\begin{array}{l}9(27 \%) \\
4(40 \%) \\
4(24 \%) \\
5(23 \%) \\
8(31 \%)\end{array}$ & $\begin{array}{r}19(58 \%) \\
6(60 \%) \\
11(64 \%) \\
16(73 \%) \\
13(50 \%)\end{array}$ & $\begin{array}{r}21(64 \%) \\
7(70 \%) \\
12(71 \%) \\
16(73 \%) \\
15(58 \%)\end{array}$ \\
\hline
\end{tabular}

Table 3 Comparison of prevalence of Lewis antigens in saliva and on red blood cells of the same individual

\begin{tabular}{|c|c|c|c|c|}
\hline & No of patients & Le $(a-b-)$ & $L e(a+b-)$ & Le $(a-b+)$ \\
\hline \multicolumn{5}{|l|}{ Alcoholic cirrhosis } \\
\hline $\begin{array}{l}\text { Saliva } \\
\text { Blood }\end{array}$ & 33 & $\begin{array}{c}5(15 \%) \\
15(46 \%)^{*}\end{array}$ & $\begin{array}{l}9(27 \%) \\
5(15 \%)\end{array}$ & $\begin{array}{l}19(58 \%) \\
13(39 \%)\end{array}$ \\
\hline $\begin{array}{l}\text { Women } \\
\text { Saliva } \\
\text { Blood }\end{array}$ & 10 & 0 & $\begin{array}{l}4(40 \%) \\
1(10 \%)\end{array}$ & $\begin{array}{l}6(60 \%) \\
4(40 \%)\end{array}$ \\
\hline $\begin{array}{l}\text { Alcoholic pancreatitis } \\
\text { Saliva } \\
\text { Blood }\end{array}$ & 17 & $\begin{array}{l}2(12 \%) \\
10(59 \%)^{*}\end{array}$ & $\begin{array}{l}4(24 \%) \\
2(12 \%)\end{array}$ & $11(64 \%)$ \\
\hline $\begin{array}{l}\text { Chronic active hepatitis } \\
\text { Saliva } \\
\text { Blood }\end{array}$ & 22 & $\begin{array}{l}1(5 \%) \\
4(18 \%)\end{array}$ & $\begin{array}{l}5(23 \%) \\
5(23 \%)\end{array}$ & $\begin{array}{l}16(72 \%) \\
13(59 \%)\end{array}$ \\
\hline $\begin{array}{l}\text { Primary biliary cirrhosis } \\
\text { Saliva } \\
\text { Blood }\end{array}$ & 26 & $4(15 \%)$ & $\begin{array}{l}9(35 \%) \\
9(35 \%)\end{array}$ & $\begin{array}{l}13(50 \%) \\
13(50 \%)\end{array}$ \\
\hline
\end{tabular}

*Significant difference between saliva and blood.

cells with the corresponding Lewis antigen. Of four sera tested from different patients, three had this ability.

No significant differences were found in the prevalence of $\mathrm{ABO}$ or rhesus blood groups (Table 4) between the tested groups.

\section{Discussion}

The method used for blood group Lewis phenotyping of erythrocytes is a conventional direct haemagglutination test' ${ }^{\prime}$ using commercial antisera and appropriate positive and negative controls. The commercial anti-Le ${ }^{b}$ antisera were of the anti-Le ${ }^{b L}$ type $^{1}$ as they detected the Le ${ }^{b}$ antigen regardless of ABO type. To produce an agglutinate, an antiserum of good avidity is required as well as a sufficient number of antigens on the red cell. The Lewis antigens on erythrocytes are glycosphingolipids ${ }^{3}$ and are not primarily synthesised on the red cell but are absorbed from plasma, where they are transported by lipoproteins. ${ }^{4}$ The origin of the Lewis antigens in plasma is unknown, but small intestinal epithelia has been suggested. ${ }^{50}$ The fact that the Lewis antigens are not synthesised per se on erythrocytes but are taken up from plasma means that the Lewis phenotype on red cells is not solely dependent on the genotype but also on a number of factors influencing the availability of glycosphingolipid antigens in plasma for uptake and on the uptake process itself. This implies that the same genotype can give rise to various phenotypes which differ on a quantitative basis. As the direct haemagglutination technique has a detection limit dependent on the number of antigens present and antibody avidity it is quite possible to assign the phenotype $\mathrm{Le}(\mathrm{a}-\mathrm{b}-)$ to an individual who has the Lewis gene but only a limited number of Lewis antigens on the erythrocyte. The Lewis antigens in saliva are glycoproteins $^{57}$ and are probably not influenced by the same factors that influence the Lewis phenotype on erythrocytes.

The discordant results of the Lewis phenotyping on red blood cells and saliva found in the alcoholic

Table 4 Prevalence of $A B O$ and rhesus blood groups in the different groups

\begin{tabular}{|c|c|c|c|c|c|c|c|}
\hline & No of patients & $\boldsymbol{A}$ & $\boldsymbol{B}$ & $O$ & $A B$ & $R h+$ & $\boldsymbol{R} \boldsymbol{h}-$ \\
\hline $\begin{array}{l}\text { Alcoholic cirrhosis } \\
\text { (Men) } \\
\text { Alcoholic cirrhosis }\end{array}$ & 51 & $29(57 \%)$ & $5(10 \%)$ & $16(31 \%)$ & $1(2 \%)$ & $41(80 \%)$ & $10(20 \%)$ \\
\hline $\begin{array}{l}\text { (Women) } \\
\text { Alcoholic pancreatitis } \\
\text { Chronic active hepatitis } \\
\text { Primary biliary cirrhosis }\end{array}$ & $\begin{array}{l}10 \\
34 \\
22 \\
26\end{array}$ & $\begin{array}{l}6(60 \%) \\
19(55 \%) \\
10(45 \%) \\
11(42 \%)\end{array}$ & $\begin{array}{l}7(21 \%) \\
.1 \\
1\end{array}\left(\begin{array}{l}5 \% \\
4 \%\end{array}\right)$ & $\begin{aligned} & 4(40 \%) \\
& 7(21 \%) \\
& 11(50 \%) \\
& 12(46 \%)\end{aligned}$ & $\begin{array}{l}1(3 \%) \\
0(8 \%) \\
2(8 \%)\end{array}$ & $\begin{array}{l}10(100 \%) \\
32 \\
16 \\
24\end{array}\left(\begin{array}{l}94 \%) \\
73 \%) \\
96 \%)\end{array}\right.$ & $\left.\left.\begin{array}{l}2 \\
6 \\
1\end{array}\right\} \begin{array}{r}6 \% \% \\
27 \%\end{array}\right)$ \\
\hline
\end{tabular}


cirrhosis, alcoholic pancreatitis, and renal disease patient groups may therefore be interpreted as an influence on the genetic expression rather than a genetic predisposition. Although only a limited number of adsorption experiments were performed using sera from patients who were Lewis positive in saliva but negative on red blood cells, the results of these experiments indicate the presence of Lewis substances in their sera.

In an attempt to elucidate the mechanisms responsible for the discordance between blood and saliva we compared some clinical and laboratory data obtained from the records in the men with alcoholic cirrhosis or alcoholic pancreatitis showing concordant and discordant results of Lewis antigen test on saliva and red blood cells. Patients with Le $(a-b-)$ phenotype in both saliva and blood were omitted from this comparison. The chosen data were thought to give some information regarding haemodilution, degree of liver and pancreatic damage, and influence of recent alcohol abuse. The number of days in hospital was used as a measure of duration of alcohol abstinence. (Table 5). The prevalence of increased serum aminotransferases was used to show the frequency of liver disturbance in the alcoholic pancreatitis group, although it was generally slight and of short duration.

The discordant results of the Lewis phenotyping on saliva and blood cells are apparently not due to liver damage, since it was not found in patients with primary biliary cirrhosis and was equally common in alcoholic pancreatitis patients with and without increased serum aminotransferases. Furthermore, patients with discordant results did not seem to have more pronounced liver damage than patients with concordant results, judged from the levels of serum bilirubin, coagulation factors II, VII, and X, serum albumin, and the presence of ascites.

The increased prevalence of the phenotype Le $(a-b-)$ in blood in patients with renal disease, as well as in pregnant women, ${ }^{5}$ suggests a reduced amount of Lewis antigens on the red blood cells. Since a normal frequency of phenotype Le $(a-b-)$ was found post partum, Hammar et al suggested that a change in lipoprotein to red cell mass ratio might produce such a reduction.

It it well known that alcoholism induces an abnormal lipid metabolism, and changes in triglyceride and high density lipoprotein (HDL) cholesterol concentrations during abstinence have been described. There are raised levels of triglycerides and HDL cholesterol during the first days of abstinence, which in most cases return to normal or even subnormal values during the second week of abstinence.$^{8-10}$ Lipid abnormalities are also found in acute pancreatitis." Whether such changes in serum lipids influence the uptake of Lewis antigen on red blood cells is speculative and cannot be deduced from this study.

Liver cirrhosis may be associated with increased plasma volume also when there are no clinical signs of fluid retention..$^{12}$ The comparison of haemoglobin concentration as an indicator of haemodilution in patients with concordant and discordant results of Lewis phenotyping gave no support for haemodilution being of importance (Table 5). Finally, a comparison of the number of days in hospital before the blood samples were drawn, as a measure of the duration of abstinence, gave no support for a direct effect of alcohol as the cause of a reduced amount of Lewis antigens on the red blood cells (Table 5).

These present results indicate that conventional blood group typing using a haemagglutination technique may be misleading in certain patient groups as well as under certain physiological conditions. ${ }^{5}$ Antisera of higher quality, possibly monoclonal, may diminish the number of missed Lewis positive individuals but will probably never be completely

Table 5 Comparison of patients with concordant and discordant results of Lewis antigen test on saliva and red blood cells

\begin{tabular}{|c|c|c|c|c|}
\hline & \multicolumn{2}{|c|}{ Alcoholic cirrhosis } & \multicolumn{2}{|l|}{ Pancreatitis } \\
\hline & Concordance & Discordance & Concordance & Discordance \\
\hline $\begin{array}{l}\text { Haemoglobin concentration }(\mathrm{g} / \mathrm{dl}) \\
\text { Serum bilirubin }(\mu \mathrm{mol} / \mathrm{l}) \\
\text { Coagulation factors II, VII, X (\%) } \\
\text { Serum creatinine }(\mu \mathrm{mol} / \mathrm{l}) \\
\text { Erythrocyte sedimentation rate (mm in }\end{array}$ & $\begin{array}{l}12 \cdot 2 \pm 1 \cdot 9(16) \\
83 \pm 103(17) \\
44 \pm 17(17) \\
94 \pm 40(17)\end{array}$ & $\begin{array}{r}12 \cdot 1 \pm 1 \cdot 6(7) \\
34 \pm 15(10) \\
48 \pm 16(10) \\
105 \pm 43(10)\end{array}$ & $\begin{array}{l}13 \cdot 1 \pm 1 \cdot 7(6) \\
15 \pm 5(6) \\
90 \pm 22(3) \\
78 \pm 15(5)\end{array}$ & $\begin{array}{l}13 \cdot 6 \pm 1 \cdot 0(8) \\
16 \pm 8(9) \\
85 \pm 30(7) \\
72 \pm 14(8)\end{array}$ \\
\hline $\begin{array}{l}\text { the first hour) } \\
\text { Urine amylase }(\mu \mathrm{kat} / \mathrm{l}) \\
\text { Prevalence of ascites }(\%) \\
\text { Prevalence of increased serum }\end{array}$ & $\begin{array}{l}39 \pm 26(16) \\
\frac{59}{(17)}\end{array}$ & $\begin{array}{l}\frac{28}{80} \pm 21(8) \\
(10)\end{array}$ & $\begin{array}{c}18 \pm 14(6) \\
67 \pm 32(6) \\
0\end{array}$ & $\begin{aligned} 26 & \pm 24(9) \\
112 & \pm 45(9) \\
0 & \end{aligned}$ \\
\hline $\begin{array}{l}\text { aminotransferases }(\%) \\
\text { Serum albumin }(\mathrm{g} / \mathrm{l}) \\
\text { No of days in hospital before blood }\end{array}$ & $\overline{29} \pm 6(12)$ & $\overline{30} \pm 8(6)$ & $\frac{50}{-}$ & $\frac{44}{-}$ \\
\hline sampling & $17 \pm 12(13)$ & $12 \pm 11(7)$ & $6 \pm 4(9)$ & $4 \pm 3(9)$ \\
\hline
\end{tabular}

Numbers in parentheses $=$ number of patients. 
safe. Lewis typing using saliva seems to be a safer but perhaps more laborious method to overcome this problem.

Our data from the determination of ABO blood group and rhesus antigens showed no differences between patients with alcoholic cirrhosis, alcoholic pancreatitis, chronic active hepatitis, and primary biliary cirrhosis. As far as the patients with alcoholic cirrhosis are concerned, previous studies have shown normal distributions of $\mathrm{ABO}$ blood group and rhesus antigens in these patients ${ }^{1314}$ but Marks and Bank found an increased frequency of blood group $\mathrm{O}$ in patients with alcoholic pancreatitis. ${ }^{15}$

Part of this work was supported by a grant from the Swedish Medical Research Council (no 6521).

\section{References}

'Mollison PL. Blood transfusion in clinical medicine. Oxford: Blackwell Scientific, 1972:396.

${ }^{2}$ Hirsch HF, Graham HA. Adsorption of $L^{c}$ and Led from plasma onto red blood cells. Transfusion 1980;20:474-5.

${ }^{3}$ Marcus DM, Cass LE. Glycosphingolipids with Lewis blood group activity. Uptake by human erythrocytes. Science 1969;164:553-5.

4 Sneath JS, Sneath PHA. Transformation of the Lewis groups of human red cells. Nature 1955;176:172.

${ }^{5}$ Hammar L, Mânsson S, Rohr T, et al. Lewis phenotype of erythrocytes and $\mathrm{Le}^{\mathrm{b}}$-active glycolipid in serum of pregnant women. Vox Sang 1981;40:27-33.

- Evans DAP, Donohoe WTA, Hewitt S, Linaker BD. Le a blood group substance degradation in the human alimentary tract and urinary $\mathrm{Le}^{\mathrm{a}}$ in Coeliac disease. Vox Sang 1982;43:177-87.

' Watkins WM. Genetis and biochemistry of some human blood groups. Proc R Soc Lond 1978;B201:31-53.

8 Johansson BG, Medhus A. Increase in plasma alfa-lipoproteins in chronic alcoholics after acute abuse. Acta Med Scand 1974; 195: 273-7.

' Danielsson B, Ekman R, Johansson BG, Kristensson H, Nilsson-Ehle P, Wadstein J. Changes in plasma high density lipoproteins in chronic male alcoholics during and after abuse. Scand J Clin Lab Invest 1978;38:113-9.

${ }^{10}$ Wallerstedt S, Gustafson A, Olsson R. Serum lipids and lipoproteins during abstinence after heavy alcohol consumption in chronic alcoholics. Scand J Clin Lab Invest 1977;37:599-604.

" Cameron JL, Capuzzi DM, Zuidema GD, Margolis S. Acute pancreatitis with hyperlipemia. Am J Med 1974;56:482-7.

12 Lieberman FL, Reynolds TB. Plasma volume in cirrhosis of liver: Its relation to portal hypertension, ascites and renal failure. $J$ Clin Invest 1967;46:1297-1308.

${ }^{13}$ Neukirchen M, Haase W. Blutgruppe, Alkoholkrankheit und leberschädigung. Münchener Medizinische Wochenschrifi 1981;123:129-32.

14 Faizallah R, Woodrow JC, Krassner NK, Walker RJ, Morris AI. Are HLA antigens important in the development of alcoholinduced liver disease? $\mathrm{Br}$ Med $J$ 1982;285:533-4.

${ }^{15}$ Marks IN, Bank S, Barbezat GO. Alkohol pankreatitis. Ätiologie, klinische formen, komplikationen. Leber Magen Darm 1976;5:257-70.

Requests for reprints to: Dr L Stigendal, Medical Department II, Sahlgrens Hospital, S-413 45 Gothenburg, Sweden. 